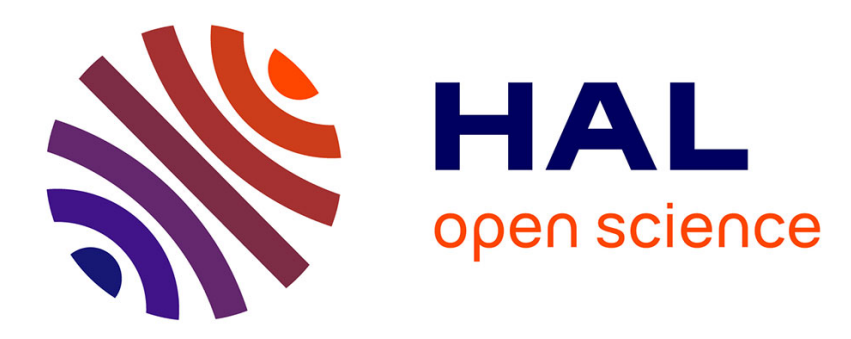

\title{
A Review of the Failure and Damage Forms of Metals under Cyclic Loading \\ S Ghorbanhosseini
}

\section{To cite this version:}

S Ghorbanhosseini. A Review of the Failure and Damage Forms of Metals under Cyclic Loading. International Journal of Current Science Research and Review, 2020, 03, 10.47191/ijcsrr/v3-i11-07 . hal-03027086

\section{HAL Id: hal-03027086 https://hal.science/hal-03027086}

Submitted on 30 Nov 2020

HAL is a multi-disciplinary open access archive for the deposit and dissemination of scientific research documents, whether they are published or not. The documents may come from teaching and research institutions in France or abroad, or from public or private research centers.
L'archive ouverte pluridisciplinaire HAL, est destinée au dépôt et à la diffusion de documents scientifiques de niveau recherche, publiés ou non, émanant des établissements d'enseignement et de recherche français ou étrangers, des laboratoires publics ou privés. 


\title{
International Journal of Current Science Research and Review
}

ISSN: 2581-8341

Volume 03 Issue 11 November 2020

DOI: 10.47191/ijcsrr/V3-i11-07, Impact Factor: 6.595

IJCSRR@ 2020

Www.ijcsrr.org

\section{A Review of the Failure and Damage Forms of Metals under Cyclic Loading}

\author{
S. Ghorbanhosseini \\ Department of mechanical engineering, Bu-Ali Sina University
}

\begin{abstract}
The studies related to metals damage under cyclic loading as the dominant form of structural failure is reviewed. The early approaches including stress-based and strain-based as well as the later approaches of energy-based, critical plane-based and damage mechanics-based are briefed on. Recent methods including thermography, finite element, and microstructural are summarized and explained. Different phenomenon occurring under cyclic loading are explained including fatigue crack initiation, crack propagation, fretting, and buckling. This review provides insight on the underlying mechanisms of different fatigue damage types and related proposed models. In addition, it explains the different aspects of each model along with their methodology.
\end{abstract}

Keywords: Fatigue, cyclic damage, finite element, microstructure, cyclic buckling, cyclic fretting

\section{Introduction}

Fatigue of metals has been the subject of study since mid- $18^{\text {th }}$ century due to its importance in structural failures. Reports show that the expenses related to fatigue failures is almost $4 \%$ of the US gross national product [1]. Throughout this time, numerous studies have taken multiple approaches to quantify fatigue damage and assess the corresponding life of mechanical components.

Different materials might be subject to different forms of failures and investigating their performance under working conditions is necessary [2-5], where both experimental and numerical analyses are required [6, 7]. Metals experience cumulative damage under cyclic loading. The microstructural changes evolve due to cyclic loading and the resulting deformations lead to permanent damage. The life of a metal under this type of loading contains fatigue crack initiation and growth regimes. Fatigue crack initiation is the time a material spends until the first critical crack is initiated, while fatigue crack growth is the time spent on the propagation of the crack until failure.

Depending on the applied cyclic load amplitude, the fatigue damage and life of a metal is modeled according to the microstructural characteristics of that loading regime. In the low cycle fatigue regime (high stress/strain amplitude) the plastic deformations and the associated energy are the dominant contributors to damage. In this loading regime, the cracks usually start from the free surface, and the propagation life is considerable of the whole. In high cycle fatigue regime (low stress/strain amplitude), however, the cracks may start from inside the material as well as from the surface depending on type of the metal. Inclusions, voids, defects and microstructural irregularities in general play a significant role in high cycle fatigue as local stress raisers. The fatigue crack growth life is less significant of the whole in this loading regime and most of the life is spent during the initiation of the critical crack.

In this paper, a comprehensive review of the fatigue models is presented based on how they quantify the accumulate damage. In section 2, cyclic damage models including stress-based, strain-based and energy-based as well as the ones predicated on critical-plane and damage mechanics are reviewed. Moreover, the recent advances such as microstructure-sensitive studies, Finite element method (FEM) and crystal plasticity finite element method (CPFEM) are explained. In section 3, special phenomenon under cyclic loading such as cyclic buckling and fretting are discussed, and the latest advances are reviewed.

\section{Cyclic Damage}

\subsection{Stress-/strain-based}

Sines quantified fatigue damage based on octahedral shear stress as shown in Eq. 1[8].

$$
\frac{\Delta \tau_{o c t}}{2}+\alpha\left(3 \sigma_{h}\right)=\beta
$$

Where $\alpha$ and $\beta$ are material properties, $\Delta \tau_{o c t}$ is the shear stress range and $\sigma_{h}$ is the hydrostatic stress.

Findley [9] proposed a similar model, where instead of octahedral shear and hydrostatic stresses, the maximum of shear stress range in the medium $(\Delta \tau)$ and a proportion of normal stress quantify the accumulated damage $\left(k \sigma_{n}\right)$.

$$
\left[\frac{\Delta \tau}{2}+k\left(3 \sigma_{n}\right)\right]_{\max }=d
$$




\section{International Journal of Current Science Research and Review}

ISSN: 2581-8341

Volume 03 Issue 11 November 2020

DOI: 10.47191/ijcsrr/V3-i11-07, Impact Factor: 6.595

IJCSRR@ 2020

Www.ijcsrr.org

Where $k$ and $d$ are determined based on the material. This model is capable of considering the effect of static or mean stresses under uniaxial and multiaxial cyclic loading.

Wang-Brown model [10] was developed to add the strain-path dependency to the earlier well-known model proposed by Brown-Miller [11] (where maximum shear and normal strain ranges on the plane with the highest shear strain range was set as the fatigue damage indicator). The Wang-Brown model incorporates elastic and plastic Poisson's ratios $\left(v_{e}\right.$ and $\left.v_{P}\right)$ as well as the effective normal strain excursion $\left(\varepsilon_{e f f}\right)$.

$$
\frac{\Delta \tau_{\max }}{2}+f \varepsilon_{\text {eff }}=\left[1+v_{e}+\left(1-v_{e}\right) f\right] \frac{\sigma_{f}^{\prime}-2 \sigma_{n_{m}}}{E}\left(2 N_{f}\right)^{b}+\left[1+v_{p}+\left(1-v_{p}\right) f\right] \varepsilon_{f}^{\prime}\left(2 N_{f}\right)^{c}
$$

Where $f$ is the multiaxiality parameter; $\sigma_{f}^{\prime}$ and $b$ are the fatigue strength coefficient and exponent, respectively; $\varepsilon_{f}^{\prime}$ and $c$ are the fatigue ductility coefficient and exponent, respectively; $2 N_{f}$ is the fatigue life. The model can predict fatigue life under proportional/non-proportional cyclic loading.

\subsection{Critical plane and damage mechanics}

The proposed models by Brown et al estimates the accumulated cyclic damage on a plane with maximum damage indicating parameter. For instance, in Eq. $3 \Delta \tau_{\max }$ is in fact the representative damage indicator in this model and is the value of $\Delta \tau$ on a plane in space where it becomes maximum. Although the proposed models by Brown et al. use critical plane approach, latter improved versions were built up on them which advanced the use of critical plane approach. One of the largely-implemented critical plane models was proposed by Fatemi-Socie [12].

$$
\frac{\Delta \gamma}{2}\left(1+K \frac{\sigma_{n, \max }}{\sigma_{y}}\right)=\frac{\tau_{f}^{\prime 2}}{G}\left(2 N_{f}\right)^{b}+\gamma_{f}^{\prime}\left(2 N_{f}\right)^{c}
$$

Where $\tau_{f}^{\prime}=\sigma_{f}^{\prime} / \sqrt{3}$ and $\gamma_{f}^{\prime}=\sqrt{3} \varepsilon_{f}^{\prime}$ are the shear fatigue strength and ductility coefficients. Eq. 4 considers the plane with the maximum shear strain range as the critical plane of damage. This model is widely implemented by the field and the advanced finite element and crystal plasticity-based simulations of fatigue damage.

Glink et al presented a model based on the shear and normal work generated on the critical plane [13].

$$
\frac{\Delta \gamma}{2} \frac{\Delta \tau}{2}+\frac{\Delta \varepsilon_{n}}{2} \frac{\Delta \sigma_{n}}{2}=\frac{\sigma_{f}^{\prime 2}}{2 E}\left(2 N_{f}\right)^{2 b}+\frac{\sigma_{f}^{\prime} \varepsilon_{f}^{\prime}}{2}\left(2 N_{f}\right)^{b+c}
$$

later on Glinka et al.[14] Proposed the following fatigue damage indicator, to account for the effect cyclic mean stress.

$$
F D I=\frac{\Delta \gamma}{2} \frac{\Delta \sigma_{n}}{2}\left(\frac{1}{1-\tau^{\max } / \tau_{f}^{\prime}}+\frac{1}{1-\sigma_{n}^{\max } / \sigma_{f}^{\prime}}\right)
$$

\subsection{Energy-based and thermography}

The energy -based approach to quantifying fatigue damage considers the accumulated strain energy under cyclic loading as the representative of the amount of damage. The simplest indication of a strain-energy based model is the multiplication of stress and strain terms in their equations. Based on this, the critical plane models of Fatemi and also Glinka are considered strain-energy based.

In recent years, the monitoring of thermal dissipations from the surface of metals has been utilized widely to quantify the accumulated plastic strain energy based on the laws of thermodynamics. Meneghetti presented a method for measuring the dissipated heat per cycle of a fatigue test, using the specimen surface temperature cooling rate [15]. In this method the experiment needs to be interrupted in the steady-state region of the temperature evolution and the cooling rate is measured. Hajshirmohamadi and Khonsari, used the initial slope of the temperature rise in a cyclic test to estimate the stress intensity factor [16, 17]. Moreover, the fatigue crack growth rate was correlated with the entropy during the test [18].

\subsection{Microstructural}

In a study on the behavior of Ni-based super alloys under cyclic loading by Chen et al [19] postulated that the locallystored strain energy and dissipated energy sites in the microstructure can be associated with the fatigue damage and crack initiation sites. Other potential fatigue damage indicators such as dislocation density were assessed in this study. It is seen that there is better coordination between the sites of fatigue crack initiation and stored strain energy/dissipated energy. 
ISSN: 2581-8341

Volume 03 Issue 11 November 2020

DOI: 10.47191/ijcsrr/V3-i11-07, Impact Factor: 6.595

IJCSRR@ 2020

www.ijcsrr.org

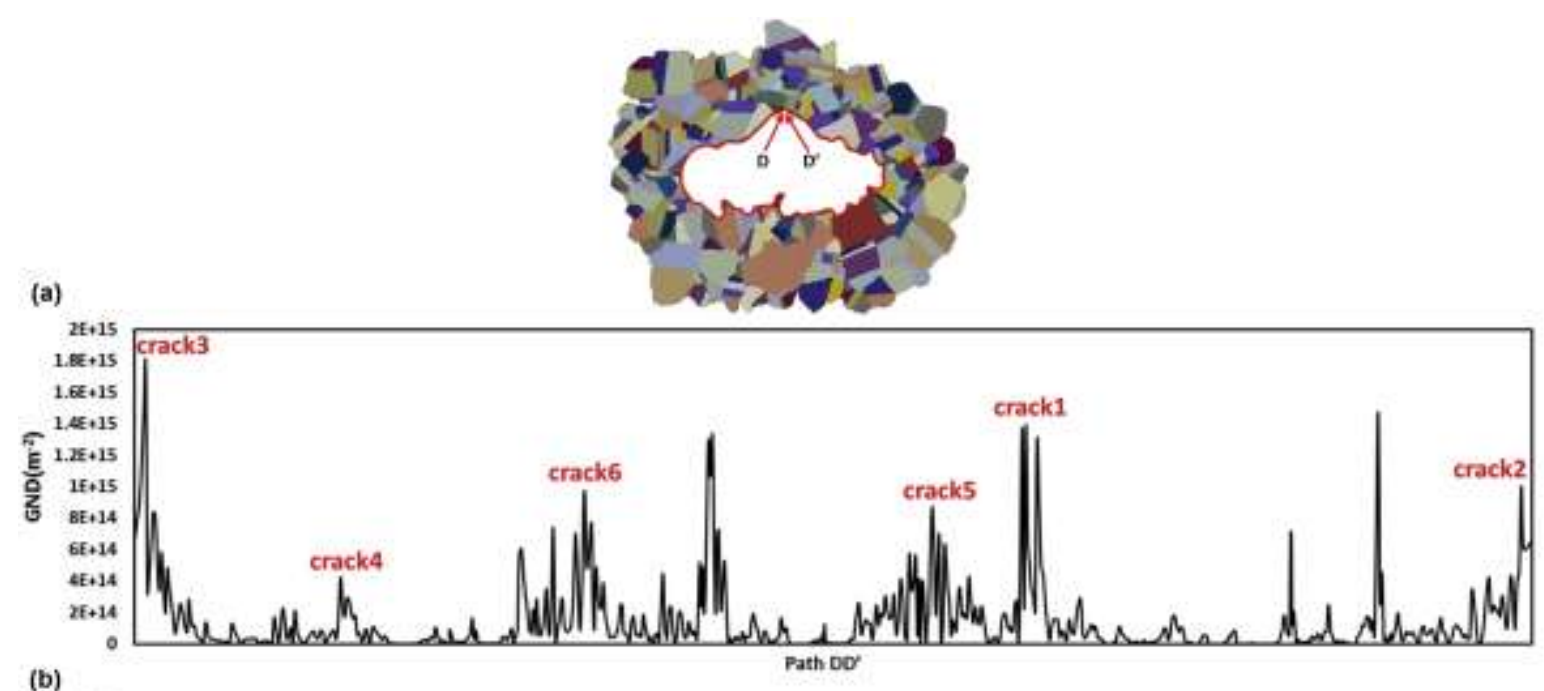

(1)
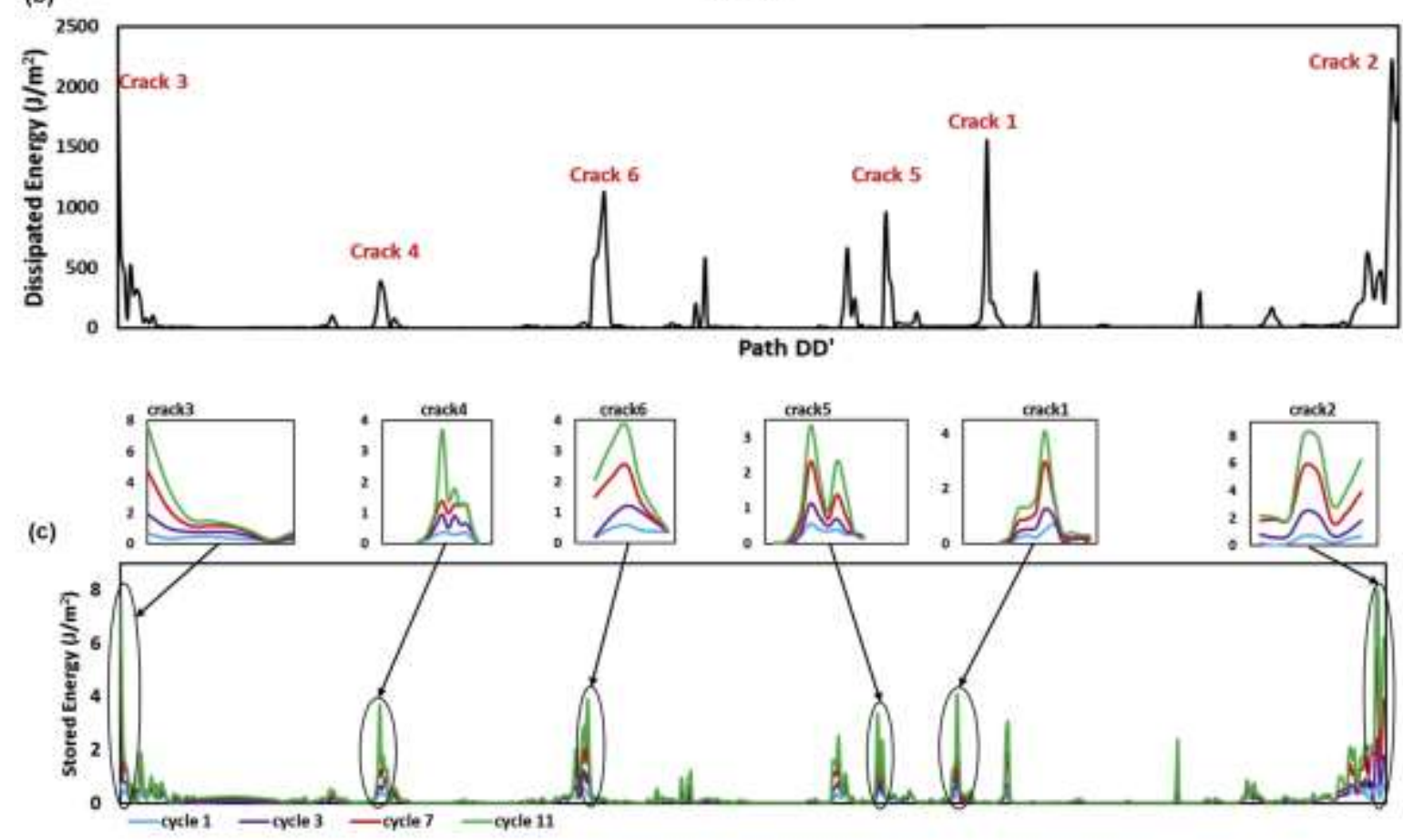

Figure 1. Nickle alloy grains with the agglomerate are tested under 3 point bending cyclic test. The initiated crack sites along the path of DD' are compared against the extremum peaks of a) Geometrically necessary dislocations b) Dissipated energy c) locallystored energy. The image is taken from the work of Chen et al. [19]

Jirandehi and Khonsari [20] developed a method for the statistical estimation of plastic strain energy (SEPSE) under cyclic loading. Knowing that the distribution of plastic strains under cyclic loading follows a Gaussian distribution, the method uses the stressstrain data from a monotonic tensile test to draw the plastic strain distribution for any cyclic load amplitude and calculate the PSE per cycle. My early evaluation of the model with Al 6061-T6 shows the method presents realistic predictions.

\subsection{FEM and CPFEM}

Using FEM and crystal plasticity, Korsunsky et al [21] assessed different microscale energy dissipation criteria and linked the crack incubation to the maximum value of the damage indicator in the model. The contribution of each active slip system $(n)$ to the accumulated shear strain energy as the damage indicator was calculated using Eq. 6. 


\section{International Journal of Current Science Research and Review}

ISSN: 2581-8341

Volume 03 Issue 11 November 2020

DOI: 10.47191/ijcsrr/V3-i11-07, Impact Factor: 6.595

IJCSRR@ 2020

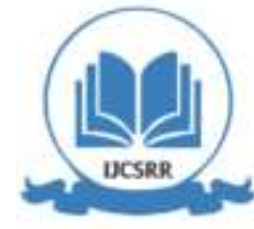

WWw.ijcsrr.org

$$
\sum_{i=1}^{n} \tau_{n} \dot{\gamma}_{n} d t
$$

Where $\tau_{n}$ and $\dot{\gamma}_{n}$ are the resolved shear stress and shear strain rate on the $n^{\text {th }}$ slip system. Accordingly, the micro-energy dissipation is calculated for nickel-based super alloy and used to obtain fatigue life.

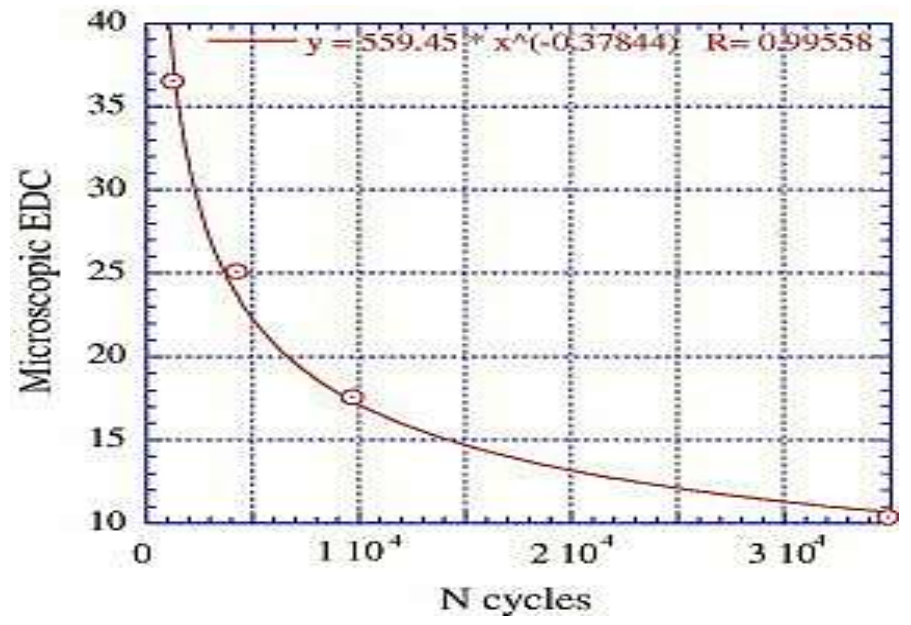

Figure 2. fatigue life predictions via the micro energy density criterion [21].

Locally-stored plastic strain energy of 718Plus Nickle-based was obtained using crystal plasticity finite element (CPFEM) simulations by Sangid et al [22]. A Bayesian framework was used to calibrate the critical plastic strain energy density. By showing that the accumulated plastic strain energy until failure is a material property, they were able to predict the fatigue lives of this material at different load amplitudes.

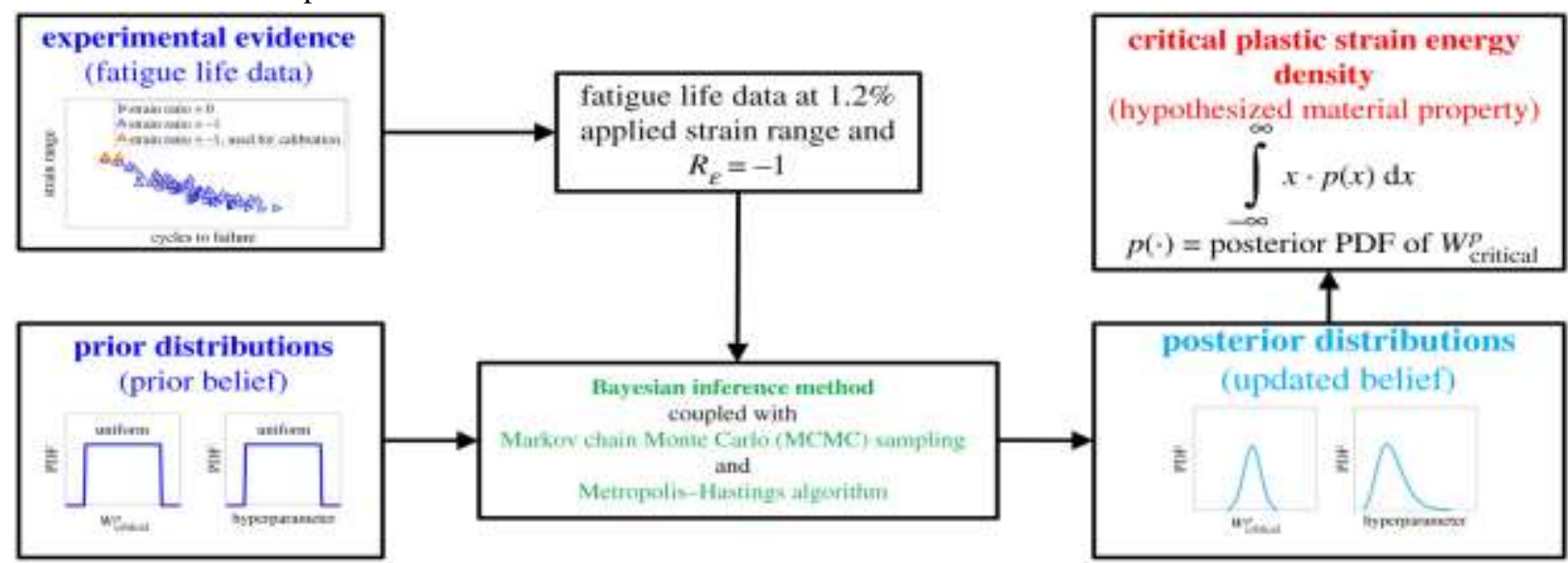

Figure 3. Bayesian framework for the calibration of plastic strain energy. The image is taken from the work of Sangid et al. [22]

Jirandehi and Chakherlou developed a finite element approach to fatigue life estimation, where 4 microstructure-inspired techniques of point, surface, volume and weighted volume were presented [23]. The performance of different multiaxial fatigue criteria based on critical plane approach and in conjunction with the proposed techniques were assessed. It was indicated that the models of FatemiSocie and Glinka showed better accuracy when used with point/surface methods, while the models Smith-Watson-Topper [24] and Findley [25] showed better life predictions when used with volume and weighted volume techniques.

\section{Special Phenomenon}

\subsection{Cyclic Buckling}

Mechanical parts might experience buckling under cyclic loading, depending on the shape of the part, the magnitude of the load, and material strength. Under excessive compression, the load carrying capacity of material diminishes and leads to crushing failure. 


\section{International Journal of Current Science Research and Review}

ISSN: 2581-8341

Volume 03 Issue 11 November 2020

DOI: 10.47191/ijesrr/V3-i11-07, Impact Factor: 6.595

IJCSRR@ 2020

Www.ijcsrr.org

Black [26] proposed a method of measuring the inelastic cyclic buckling limit of metals. The method includes extracting the hysteresis stress-strain curve and obtaining the tangent modulus for each loop to be used in the following equation.

$$
\frac{L_{e f f}}{r}=\sqrt{\frac{\pi^{2} E_{t}}{\sigma_{c r}}}
$$

The term on the left side is the slenderness ration, $E_{t}$ is the elastic modulus and $\sigma_{c r}$ is the critical stress limit for buckling. Recently, Jirandehi et al [27] presented a thermodynamic-base criterion for the determination of the critical inelastic cyclic buckling of ductile metals. By monitoring they observed that a critical temperature has to be reached for the temperature-induced inelastic cyclic buckling to occur. Accordingly, the calculated the critical stress level below which there is no sign of such occurrence.

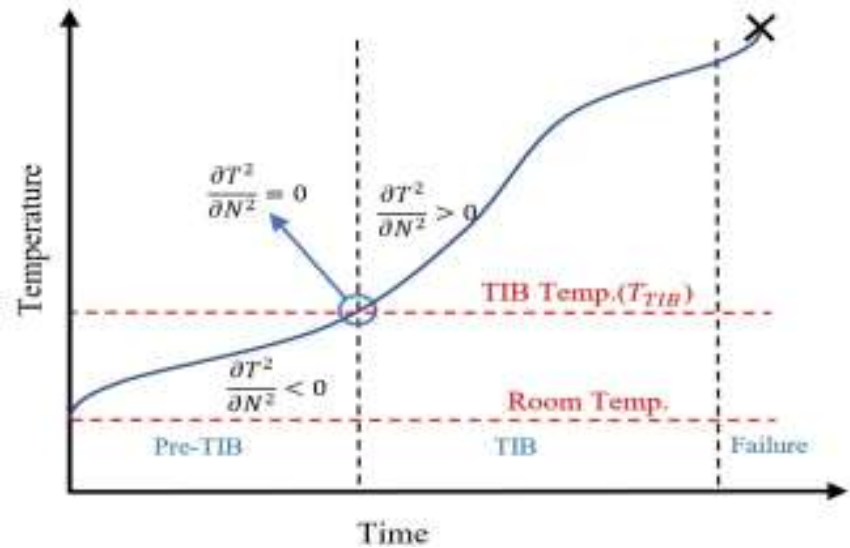

Figure 4. The temperature evolution of a ductile specimen subject to temperature-induced buckling (TIB). The inflection point indicates the critical temperature of TIB. The image is taken from the work of Jirandehi et al. [27]

\subsection{Cyclic Fretting}

Fretting is characterized by minuscule movement of two surfaces on each other. When two solid surfaces get into contact, they apply a distribution of pressure on each other which is called Hertzman distribution. If a relative displacement is enforced between the two contacting faces, there would be a distribution of friction force involved. The following figure showed the schematic of fretting.

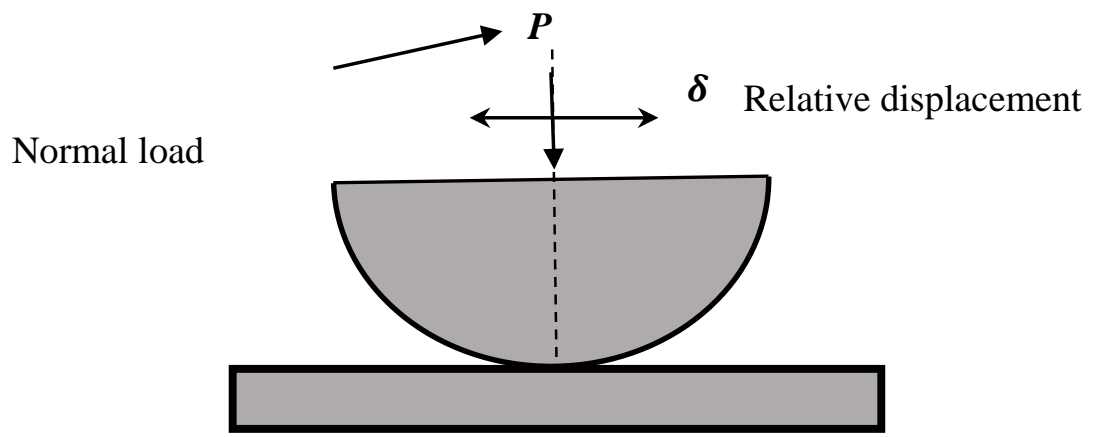

Fig. 4 Schematic of fretting between two sold surfaces [28].

As it is seen in Fig. 4, the two surface are pushing to each other with normal load, P and the relative displacement $\boldsymbol{\delta}$, is applied on the contact area. Fretting is one of the reasons for decreasing fatigue life of variety of components. Fretting occurs in metallic structures, orthopedic parts, turbines and artillery. Since the problem is a major reasons of failure in components, it needs to be investigated and signs of fretting has to be meticulously looked for. Based on the amplitude of the relative displacement and friction between the surfaces in contact, fretting is divided into two major areas. The fretting fatigue and fretting wear. Fretting fatigue is mostly the damage which occurs in structures with low amplitude of relative movement and the fretting wear is the signature of higher relative movement between the surfaces in contact. Based on the area of retting, the damage related happens with distinct 


\section{International Journal of Current Science Research and Review}

ISSN: 2581-8341

Volume 03 Issue 11 November 2020

DOI: 10.47191/ijcsrr/V3-i11-07, Impact Factor: 6.595

IJCSRR@ 2020

WWw.ijcsrr.org

mechanisms. When the amplitude of relative displacement is high the microcracks which are formed as a result of cyclic loading on the component, tent to wear off and fretting has minimal effect on the fatigue life in such circumstances. However, if the relative displacement is small, fretting is a major reason for initiating and propagation of cracks on the surface of the solid.

As the two surfaces get into contact and the relative displacement is applied, if the friction is high enough to keep the two surfaces from growth sliding on each other, there would form two distinct regions in the contact area. In the center of the contact region, the two surfaces would stick two each other and by cyclic movement of the two surfaces, the two bodies in contact do not slide on each other. However, around the edges of contact, the two surfaces slide slightly on each other. The boundary between these two regions is the location of crack nucleation due two discontinuity of friction stress on this point. This is shown in detail in the following figure.

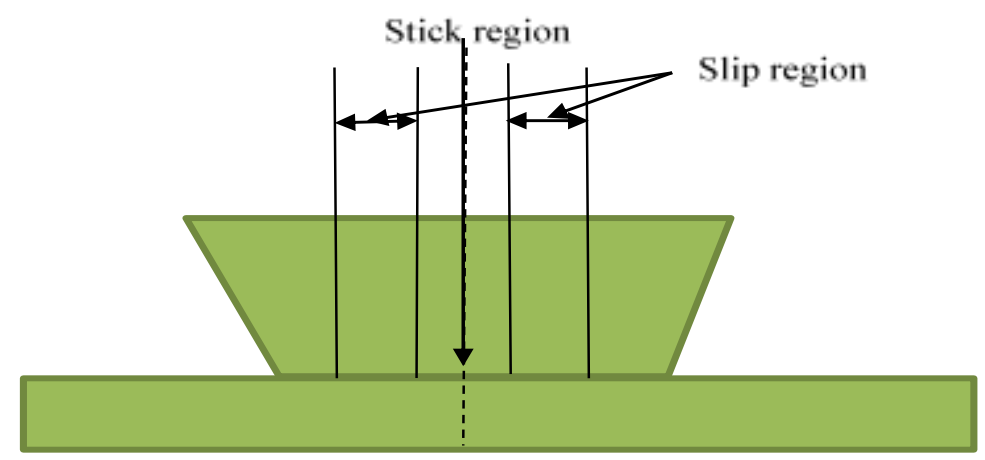

Figure 5. The formation of fretting stick and slip regions due to the contact between two surfaces

\section{Summary and Conclusion}

Recent and conventional studies related to cyclic damage were reviewed. To this end, cyclic damage models were identified as stress/strain based, critical plane/damage mechanics-based, strain energy/thermography, microstructure sensitive and FEM/ CPFEM. Special phenomenon such as cyclic buckling and fretting were discussed and the latest advances on them were reported.

In order to come up with accurate predictions of fatigue life, the underlying micro scale mechanism of the phenomenon is required. Microstructure-based models of fatigue damage take into account the evolution/movement of dislocations, veins, and slip bands under loading. On way the evolution is accounted for is by means of the change in their density. Another way is by considering the effect they have on the generated energy in the material, or the dissipated heat into the environment. This direct consideration of the underlying microscale damage mechanism enables these models to provide reliable accuracy in different loading and environmental conditions. Therefore, the approach is worthy of more investment and investigation, although the high computational and experimental resources for these approaches might be a limiting factor.

\section{References}

1. R.I. Stephens, A. Fatemi, R.R. Stephens, H.O. Fuchs, Metal fatigue in engineering, John Wiley \& Sons 2000.

2. M.A. Notani, A. Arabzadeh, S. Satvati, M.T. Tabesh, N.G. Hashjin, S. Estakhri, M. Alizadeh, Investigating the hightemperature performance and activation energy of carbon black-modified asphalt binder, SN Applied Sciences 2(2) (2020) 303.

3. Y. Wu, J.C. Ashlock, B. Cetin, S. Satvati, C. Li, H. Ceylan, Mechanistic Performance Evaluation of Chemically and Mechanically Stabilized Granular Roadways, Geo-Congress 2020: Geotechnical Earthquake Engineering and Special Topics, American Society of Civil Engineers Reston, VA, 2020, pp. 591-601.

4. S. Satvati, B. Cetin, J.C. Ashlock, C. Li, Investigation of the Performance of Different Surface Aggregate Materials for Granular Roads, Geo-Congress 2020: Geotechnical Earthquake Engineering and Special Topics, American Society of Civil Engineers Reston, VA, 2020, pp. 498-507.

5. S. Satvati, M.A. Rowshanzamir, S.M. Hejazi, A Copmparison Between The Bearing Capacities Of Strip Footing On Soil Slope Reinforced By Plannar And Tubular Form Of Braid And Geogrid Elements. 


\section{International Journal of Current Science Research and Review}

ISSN: 2581-8341

Volume 03 Issue 11 November 2020

DOI: 10.47191/ijcsrr/V3-i11-07, Impact Factor: 6.595

IJCSRR@ 2020

Www.ijcsrr.org

6. M.C. McNamara, A.E. Niaraki-Asli, J. Guo, J. Okuzono, R. Montazami, N.N. Hashemi, Enhancing the Conductivity of Cell-Laden Alginate Microfibers With Aqueous Graphene for Neural Applications, Frontiers in Materials 7 (2020) 61.

7. M. Kiani, E. Houshfar, A.E. Niaraki Asli, M. Ashjaee, Combustion of syngas in intersecting burners using the interferometry method, Energy \& Fuels 31(9) (2017) 10121-10132.

8. G. Sines, Behavior of metals under complex static and alternating stresses, Metal fatigue 1 (1959) 145-169.

9. W.N. Findley, A theory for the effect of mean stress on fatigue of metals under combined torsion and axial load or bending, Journal of Engineering for Industry 81(4) (1959) 301-305.

10. C. Wang, M. Brown, A path-independent parameter for fatigue under proportional and non-proportional loading, Fatigue $\&$ fracture of engineering materials \& structures 16(12) (1993) 1285-1297.

11. M. Brown, K. Miller, Two decades of progress in the assessment of multiaxial low-cycle fatigue life, Low-cycle fatigue and life prediction, ASTM International1982.

12. A. Fatemi, D.F. Socie, A critical plane approach to multiaxial fatigue damage including out-of-phase loading, Fatigue \& Fracture of Engineering Materials \& Structures 11(3) (1988) 149-165.

13. G. Glinka, G. Shen, A. Plumtree, A multiaxial fatigue strain energy density parameter related to the critical fracture plane, Fatigue \& Fracture of Engineering Materials \& Structures 18(1) (1995) 37-46.

14. G. Glinka, G. Wang, A. Plumtree, Mean stress effects in multiaxial fatigue, Fatigue \& fracture of engineering materials \& structures 18(7-8) (1995) 755-764.

15. G. Meneghetti, Analysis of the fatigue strength of a stainless steel based on the energy dissipation, International journal of fatigue 29(1) (2007) 81-94.

16. B. Hajshirmohammadi, M. Khonsari, Thermographic evaluation of metal crack propagation during cyclic loading, Theoretical and Applied Fracture Mechanics 105 (2020) 102385.

17. B. Hajshirmohammadi, M. Khonsari, A simple approach for predicting fatigue crack propagation rate based on thermography, Theoretical and Applied Fracture Mechanics 107 (2020) 102534.

18. B. Hajshirmohammadi, M. Khonsari, On the entropy of fatigue crack propagation, International Journal of Fatigue 133 (2020) 105413.

19. B. Chen, J. Jiang, F.P. Dunne, Is stored energy density the primary meso-scale mechanistic driver for fatigue crack nucleation?, International Journal of Plasticity 101 (2018) 213-229.

20. A.P. Jirandehi, M. Khonsari, On the determination of cyclic plastic strain energy with the provision for microplasticity, International Journal of Fatigue 142 (2020) 105966.

21. A.M. Korsunsky, D. Dini, F.P. Dunne, M.J. Walsh, Comparative assessment of dissipated energy and other fatigue criteria, International journal of fatigue 29(9-11) (2007) 1990-1995.

22. R. Bandyopadhyay, V. Prithivirajan, A.D. Peralta, M.D. Sangid, Microstructure-sensitive critical plastic strain energy density criterion for fatigue life prediction across various loading regimes, Proceedings of the Royal Society A 476(2236) (2020) 20190766.

23. A.P. Jirandehi, T. Chakherlou, A fatigue crack initiation and growth life estimation method in single-bolted connections, The Journal of Strain Analysis for Engineering Design 54(2) (2019) 79-94.

24. K.N. Smith, T.H. Topper, P. Watson, A stress-strain function for the fatigue of metals, Waterloo, Ontario, 1969.

25. W.N. Findley, P.N. Mathur, Modified theories of fatigue failure under combined stress, 1954.

26. R.G. Black, W. Wenger, E.P. Popov, Inelastic buckling of steel struts under cyclic load reversals, (1980).

27. A.P. Jirandehi, M. Mehdizadeh, M. Khonsari, Temperature-induced buckling of ductile metals during cyclic loading and the subsequent early fracture, International Journal of Mechanical Sciences 176 (2020) 105525.

28. A. Mousavi, Finite Element Investigation of Thermal Distribution in Fretting Fatigue, (2008).

Cite this Article: S. Ghorbanhosseini (2020). A Review of the Failure and Damage Forms of Metals under Cyclic Loading.

International Journal of Current Science Research and Review, 3(11), 178-184 